$\omega 1125.7$

R299

No.272

Report 272

\title{
LAND-SURFACE SUBSIDENCE \\ IN THE TEXAS COASTAL REGION
}

Eovernment Publloatlons

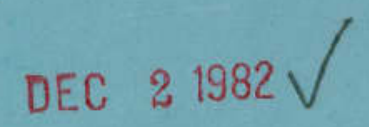

Dallas Public Library

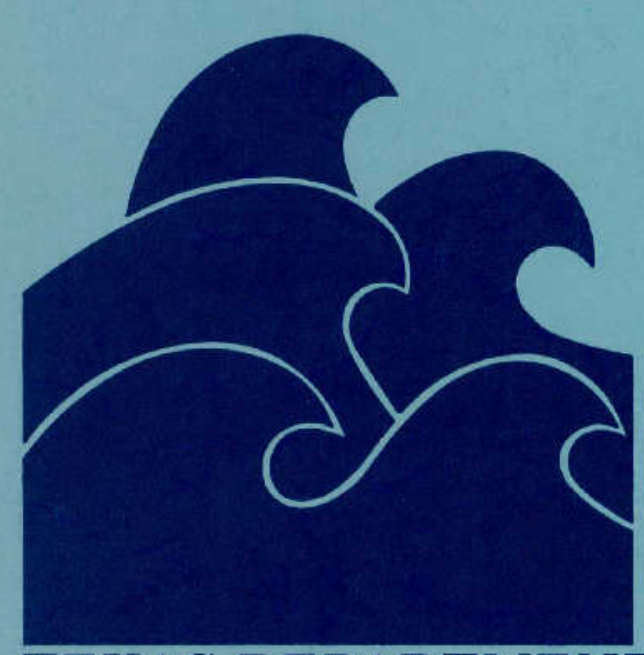





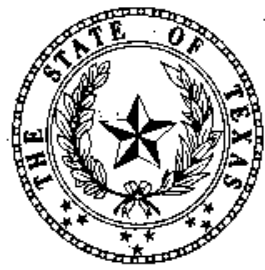

\title{
TEXAS DEPARTMENT OF WATER RESOURCES
}

\author{
REPORT 272
}

\section{LAND-SURFACE SUBSIDENCE IN THE \\ TEXAS COASTAL REGION}

By

Karl W. Ratzlaff

U.S. Geological Survey

This report was prepared by the U.S. Geological Survey under cooperative agreement with the

Texas Department of Water Resources 


\section{TEXAS DEPARTMENT OF WATER RESOURCES}

Harvey Davis, Executive Director

\section{TEXAS WATER DEVELOPMENT BOARD}

Louis A. Beecherl Jr., Chairman

Glen E. Roney

W. O. Bankston
George W. McCleskey, Vice Chairman Lonnie A. "Bo" Pilgrim

Louie Welch

\section{TEXAS WATER COMMISSION}

Lee B. M. Biggart, Chairman

Felix McDonald, Commissioner

John D. Stover, Commissioner

Authorization for use or reproduction of any original material contained in this publication, ie., not obtained from other sources, is freely granted. The Department would appreciate acknowledgement.

Published and distributed by the

Texas Department of Water Resources

Post Office Box 13087

Austin. Texas 78711 


\section{TABLE OF CONTENTS}

Page

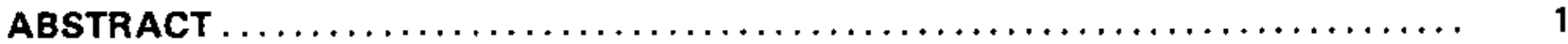

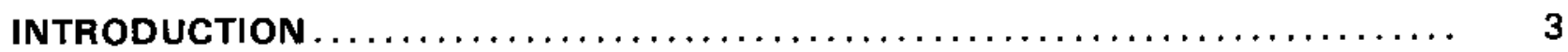

Purpose and Scope of This Report $\ldots \ldots \ldots \ldots \ldots \ldots \ldots \ldots \ldots \ldots \ldots \ldots \ldots \ldots$

Location and Extent of the Area $\ldots \ldots \ldots \ldots \ldots \ldots \ldots \ldots \ldots \ldots \ldots \ldots \ldots \ldots$

Acknowledgments $\ldots \ldots \ldots \ldots \ldots \ldots \ldots \ldots \ldots \ldots \ldots \ldots \ldots \ldots \ldots \ldots \ldots$

Metric Conversions $\ldots \ldots \ldots \ldots \ldots \ldots \ldots \ldots \ldots \ldots \ldots \ldots \ldots \ldots \ldots \ldots \ldots$

LAND-SURFACE SUBSIDENCE $\ldots \ldots \ldots \ldots \ldots \ldots \ldots \ldots \ldots \ldots \ldots \ldots \ldots \ldots \ldots \ldots \ldots$

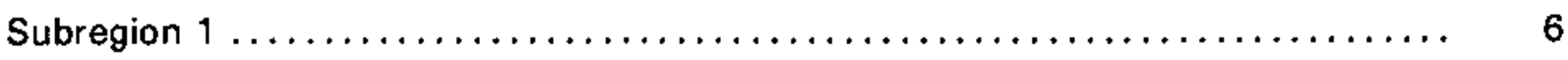

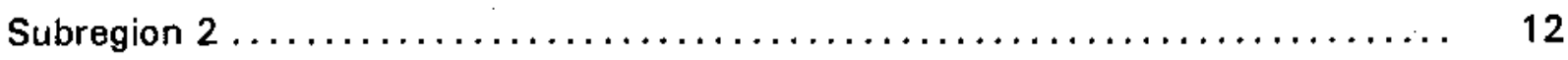

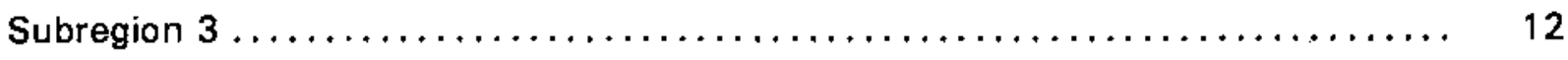

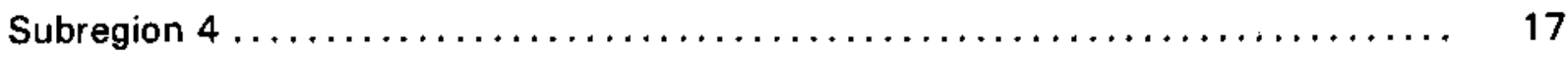

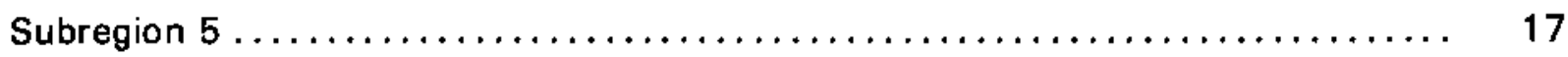

SELECTED REFERENCES $\ldots \ldots \ldots \ldots \ldots \ldots \ldots \ldots \ldots \ldots \ldots \ldots \ldots \ldots \ldots \ldots \ldots$

\section{FIGURES}

1. Map Showing Location of the Texas Coastal Region and Subregions .......... 4

2-8. Maps Showing Land-Surface Subsidence in:

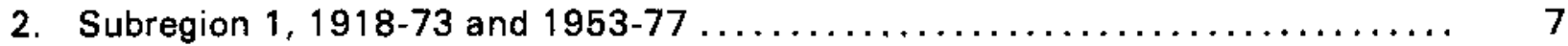

3. The Spindletop Dome Area, $1925-77 \ldots \ldots \ldots \ldots \ldots \ldots \ldots \ldots \ldots \ldots \ldots \ldots$

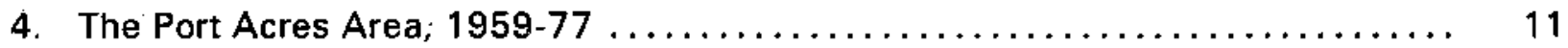

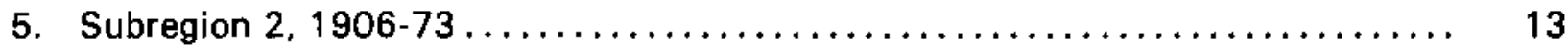

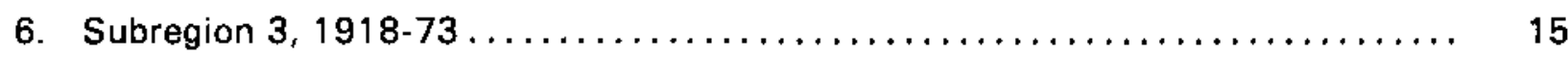

7. Subregion $4,1918-51$ and $1942-75 \ldots \ldots \ldots \ldots \ldots \ldots \ldots \ldots \ldots \ldots \ldots \ldots \ldots$

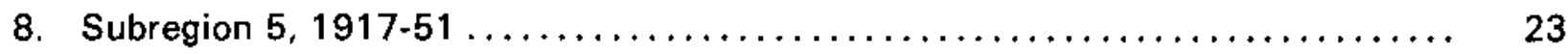





\title{
LAND-SURFACE SUBSIDENCE IN THE TEXAS COASTAL REGION
}

\author{
By \\ Karl W. Ratzlaff \\ U.S. Geological Survey
}

\begin{abstract}
Land-surface subsidence has been mapped in the Houston-Galveston area and is known to have occurred in other areas within the Texas coastal region. Most of the subsidence has been caused by both the withdrawal of ground water and by the production of oil, gas, and associated ground water.

Land-surface subsidence was determined by comparing adjusted elevations of bench marks for various periods of releveling and by comparing topographic maps of the same areas for different years. In general, most of the Texas coastal region has subsided less than 0.5 foot 10.15 meter). The largest amount of subsidence measured in the region is in the Pasadena-Houston Ship Channel area, where the land surface subsided between 8.5 and 9.0 feet (2.6 and 2.7 meters) during 1906-73. The cause of the subsidence in this area was ground-water withdrawals. Local subsidence caused by sulfur mining in the Moss Bluff Salt Dome area has been reported to exceed 15 feet ( 4.6 meters).

In Jefferson County, the Spindletop Dome area subsided approximately 5 feet (1.5 meters) during 1925-77, and the Port Acres area subsided about 3 feet (0.9 meter) during 1959-77, mainly from the withdrawal of oil or gas and associated ground water. Local subsidence caused by sulfur mining in the Spindletop Dome area has been estimated to exceed 10 feet ( 3.0 meters).

In southeastern Jackson County and northwestern Matagorda County, the land surface subsided more than 1.5 feet ( 0.46 meter) during $1943-73$ as a result of ground-water withdrawals. Withdrawals of oil, gas, and associated ground water caused more than 5 feet $\$ 1.5$ meters) of subsidence during 1942-75 in the western part of Corpus Christi in Nueces County.
\end{abstract}




\title{
LAND-SURFACE SUBSIDENCE IN THE \\ TEXAS COASTAL REGION
}

\author{
INTRODUCTION
}

\section{Purpose and Scope of This Report}

The purpose of this report, which was prepared in cooperation with the Texas Department of Water Resources, is to document the available information on land-surface subsidence in the Texas coastal region.

The scope of the project was limited to the collection and analysis of readily available subsidence data, but includes brief discussions of the causes of subsidence and the methods of determining subsidence.

\section{Location and Extent of the Area}

The Texas coastal region (Figure 1), as used in this report, includes all or parts of 27 counties and has an area of approximately 23,400 square miles $\left(60,600 \mathrm{~km}^{2}\right)$. The region is bounded on the east by the Texas-Louisiana border and on the south by the international boundary between the United States and Mexico. The width of the region ranges from 40 to 92 miles (64 to $148 \mathrm{~km}$ ) and averages about 64 miles $(103 \mathrm{~km})$. The distance from Orange to Brownsville, which are at the extreme ends of the region, is 468 miles $(753 \mathrm{~km})$.

The region is divided into five subregions (Figure 1). Subregion 1 includes all of Hardin, Jefferson, and Orange Counties, and the southern parts of Jasper and Newton Counties. Subregion 2 includes all of Brazoria, Chambers, Fort Bend, Galveston, Harris, and Liberty Counties. Subregion 3 includes all of Calhoun, Jackson, Matagorda, Victoria, and Wharton Counties. Subregion 4 includes all of Aransas, Jim Wells, Kleberg, Nueces, Refugio, and San Patricio Counties. Subregion 5 includes all of Brooks, Cameron, Kenedy, Hidalgo, and Willacy Counties. 


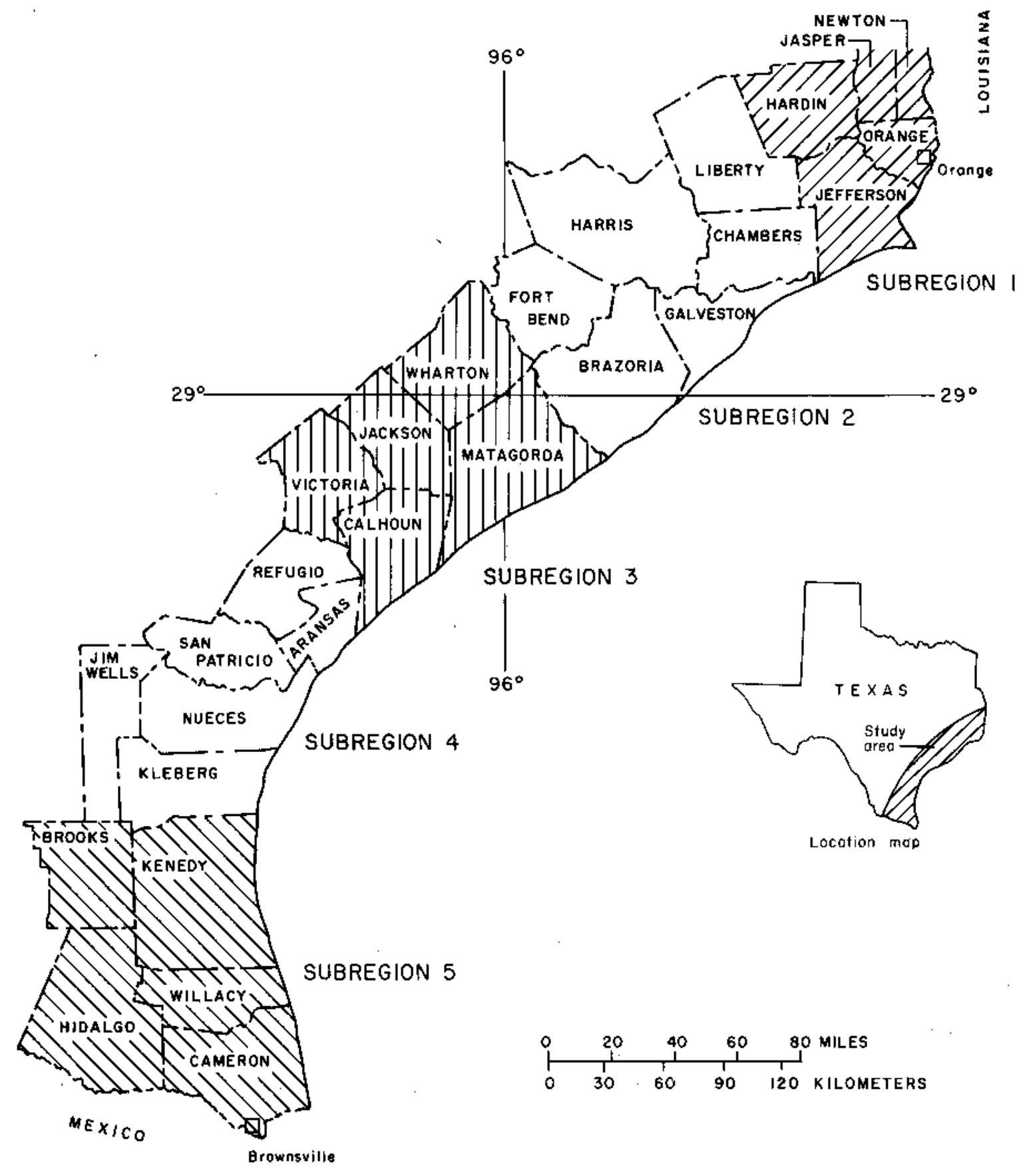

Figure 1.-Location of the Texas Coastal Region and Subregions

\section{Acknowledgments}

Appreciation is expressed to the Texas Department of Highways and Public Transportation for providing unpublished vertical-control data in subregions 4 and 5; to the Texas Department of Water Resources for providing vertical-control data in subregion 4; to Mr. L. D: Bryant, Manager, and Mr. W. C. Vittum, Engineer, Jefferson County Drainage District No. 7, for providing verticalcontrol data and a topographic map of the drainage district; and to Carl Kohler, Jr., for making available a 1925 topographic map of Jefferson County. 


\section{Metric Conversions}

Metric equivalents of the inch-pound measurements used in this report are given in parentheses. The metric equivalents may be calculated by use of the following conversion factors:

\begin{tabular}{lcl}
\multicolumn{1}{l}{ From } & Multiply by & \multicolumn{1}{c}{ To obtain } \\
foot & 0.3048 & meter $(\mathrm{m})$ \\
mile & 1.609 & kilometer $(\mathrm{km})$ \\
pound per square inch & 0.07031 & $\begin{array}{l}\text { kilogram per square } \\
\text { centimeter }\left(\mathrm{kg} / \mathrm{cm}^{2}\right)\end{array}$ \\
square mile & 2.590 & square $k i l o m e t e r\left(\mathrm{~km}^{2}\right)$
\end{tabular}

\section{LAND-SURFACE SUBSIDENCE}

The primary cause of land-surface subsidence in the Texas coastal region is the withdrawal of ground water and oil, gas, and ground water associated with the production of oil and gas. Subsidence in local areas may result from sulfur mining.

When water is withdrawn from an artesian aquifer, an immediate decrease in pore pressure occurs, which causes an equivalent increase in pressure on the aquifer skeleton. Adjustment to the changes in pore pressure in the coarse-grained (sand) beds of the artesian aquifer is instantaneous (Poland and Davis, 1969, p. 196), while the adjustments in the fine-grained (clay, silt, silty-clay) beds of the aquifer is slow. Thus a pressure difference between the sands and clays is established that causes water to move fróm the clays into the sands, which allows the clays to compact. The compaction results in a decrease in land-surface elevation. Because compacted clays are relatively inelastic, most of the subsidence is permanent.

The same principles involved in the withdrawal of ground water apply to the withdrawal of fluids related to oil and gas production. However, there are differences in reservoir properties and in the magnitude of man-made stresses involved. Oil and gas reservoirs are commonly older, deeper, more consolidated, and have less areal extent. These reservoirs have relatively small permeabilities and porosity, and the reduction in fluid pressure in the producing zones may be 20 times greater than that for ground-water reservoirs.

Land-surface subsidence in the study area was determined by comparing bench-mark elevations for different periods of leveling. The data were obtained from lists of adjusted elevations published by the National Geodetic Survey for the various periods. Additional elevation data were obtained from the Texas Department of Highways and Public Transportation and the Texas Department of Water Resources. In subregion 1 (Figure 1), topographic maps were also used to delineate land-surface subsidence.

The bench marks shown on the illustrations in this report are those that had a net loss in elevation. The time period for the corresponding losses is not necessarily the same throughout a 
subregion; consequently, the subsidence contours shown for each subregion are based on known and projected values for the most prevalent time period. Special symbols on the illustrations are given to those bench marks that represent the maximum time period between level runs. ,

The standard of accuracy for bench-mark elevations used in this report is given by the National Ocean Survey (1974). The standard for first order leveling is described as follows: "The lines are divided into sections 1 to $2 \mathrm{~km}$ in length, and each section is leveled forward and backward. The difference in the two levelings must not exceed $3.0 \mathrm{~mm}$ [millimeters] $(K)^{1 / 2}$ for Class I (Basic Net A), or $4.0 \mathrm{~mm}$ (K) ${ }^{1 / 2}$ for Class II (Basic Net $B$ ), where $K$ is the distance in kilometers."

The standard for second order, Class I leveling is described as follows: "All lines should be divided into sections 1 to $2 \mathrm{~km}$ in length, and each section should be run forward and backward, the two runnings of a section not to differ more than $6 \mathrm{~mm}(K)^{1 / 2}$ where $K$ is the length of the section in kilometers."

The standard for second order Class II leveling is described as follows: "For double-run leveling, the line should be divided into sections of 1 to $3 \mathrm{~km}$, and the forward and backward running of each section should differ by not more than $8 \mathrm{~mm}(\mathrm{~K})^{1 / 2}$ where $\mathrm{K}$ is the distance in kilometers."

The standard of accuracy for a $1.24-\mathrm{mile}(2.0-\mathrm{km})$ first-order section for Class 1 is 0.014 foot $(0.004 \mathrm{~m})$, and for Class II it is 0.018 foot $(0.005 \mathrm{~m})$. The standard of accuracy for a $1.24-\mathrm{mile}(2.0$ $\mathrm{km}$ ) second-order Class I section is 0.029 foot $(0.009 \mathrm{~m})$, and for a $1.86-\mathrm{mile}(3.0-\mathrm{km})$ secondorder Class II section it is 0.045 foot $(0.014 \mathrm{~m})$. The standards of accuracy are important when considering elevation differences of less than 0.05 foot $(0.015 \mathrm{~m})$. Elevation differences of this magnitude are common in subregion 5 .

Land-surface subsidence in the Texas coastal region is generally less than 0.5 foot $(0.15 \mathrm{~m})$; however, two large areas where land-surface subsidence exceeds 0.5 foot $(0.15 \mathrm{~m})$ are the Houston-Galveston area in subregion 2 and a rice irrigation area in subregion 3 . Elsewhere in the coastal region, subsidence exceeding 0.5 foot $(0.15 \mathrm{~m})$ is more localized.

\section{Subregion 1}

Land-surface subsidence from 1918 to 1977 in subregion 1 is generally less than 0.5 foot or $0.15 \mathrm{~m}$ (Figure 2), but subsidence has exceeded 1.0 foot $(0.3 \mathrm{~m})$ in the Spindletop Dome area and the Port Acres area. Land-surface subsidence in the Spindletop Dome area (Figure 3 ) is related to the withdrawal of oil, gas, associated ground water, and the solution mining of sulfur. The maximum subsidence attributable to withdrawal of oil, gas, and associated ground water is approximately 5 feet $(1.5 \mathrm{~m})$, which was determined by comparing a 1925 topographic map of Jefferson County with a 1977 topographic map of Jefferson County Drainage District No. 7.

With regard to subsidence due to the sulfur mining, Wesselman (1971, p. 25) states that, "Extremely localized subsidence sometimes takes place when sulfur is removed from the cap rock of the salt domes by the Frasch process. ** The Frasch process of removing sulfur has been initiated at the Fannett and Spindletop Domes in the last decade but noticeable subsidence that 


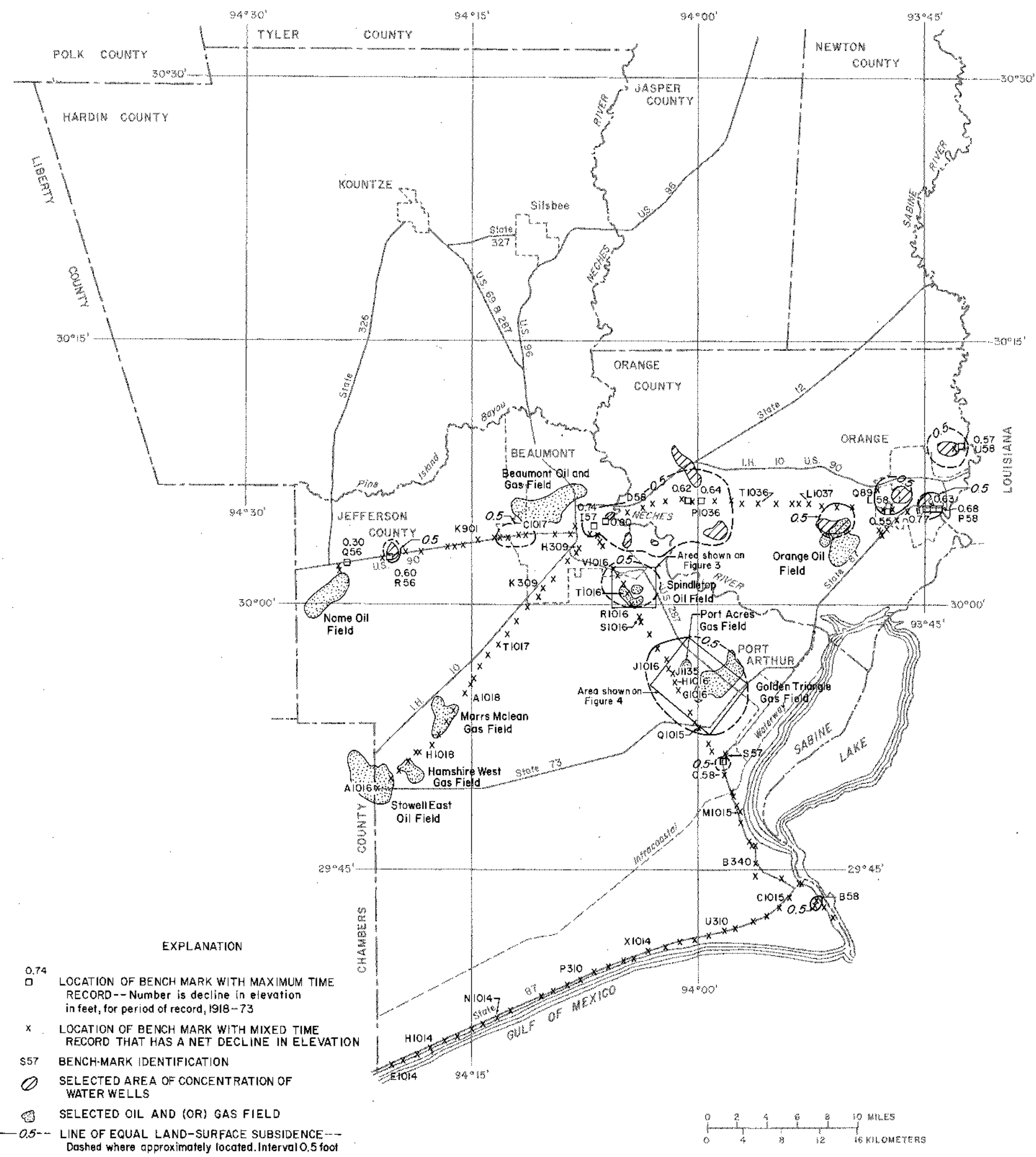

NOTE: Lines of equol subsidence are based on all data available from 19.18

Figure 2

Land-Surface Subsidence in Subregion 1, 1918-73 and 1953-77 

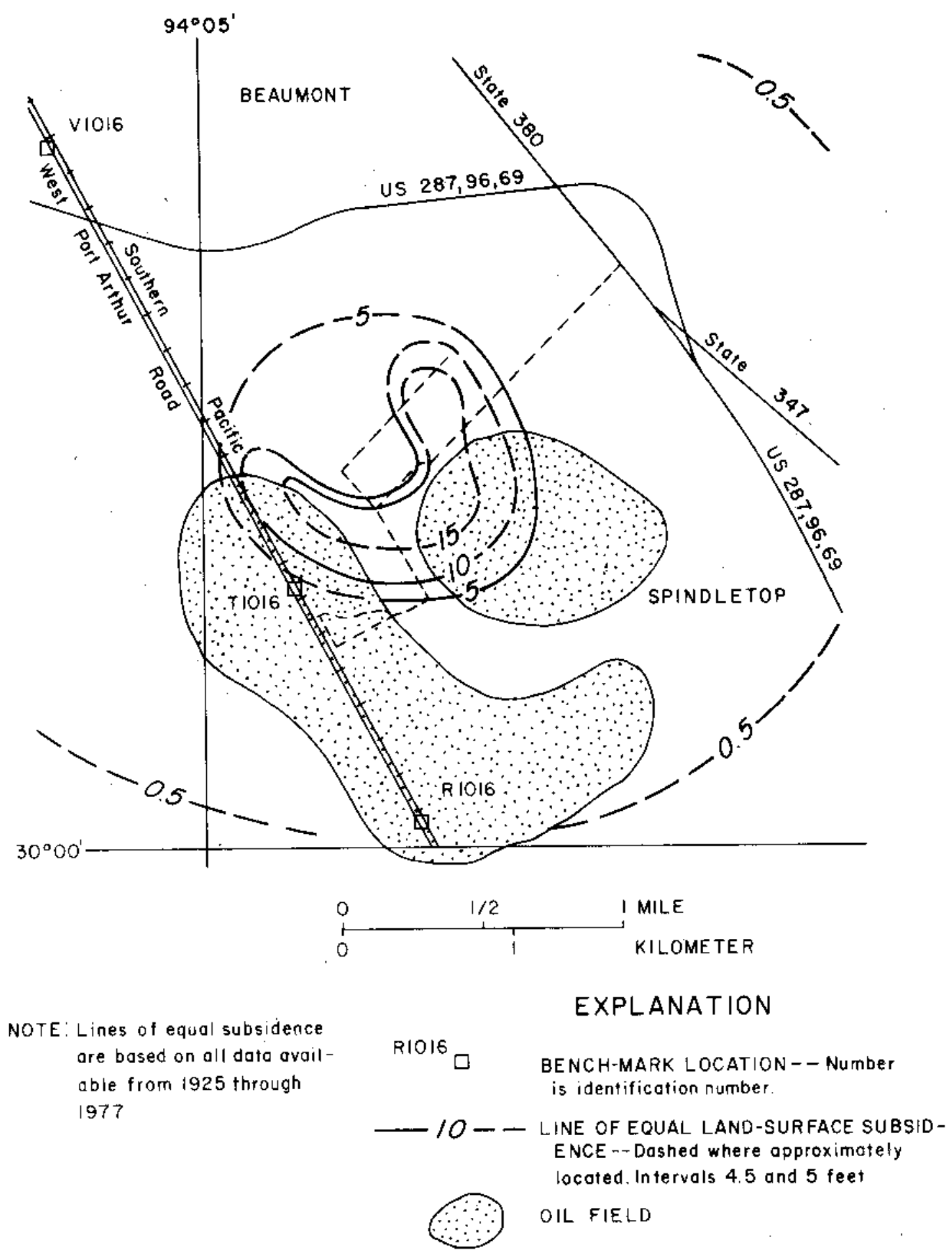

Figure 3

Land-Surface Subsidence in the Spindletop Dome Area, 1925.77

Bose from U.S. Geological Survey

topographic quadrangles 
could be attributed to this cause was not found during this study." However, an arcuate depression, indicating that subsidence caused by removal of sulfur has occurred, is shown on the Jefferson County Drainage District No. 7 (1977) topographic map, but is not present on the Beaumont East (1960) topographic map. On-site observations verified that the depression exists.

The amount of subsidence attributable to the sulfur mining cannot be easily determined from the maps because part of the depression is filled with water. Comparison of contours on the 1960 and 1977 topographic maps indicates a difference in elevation of approximately 15 feet (4.6 m) at the deepest part of the depression. By subtracting the 5 feet $(1.5 \mathrm{~m})$ of subsidence caused by the withdrawal of oil, gas, and associated ground water, the subsidence attributable to sulfur mining is estimated to exceed 10 feet $(3.0 \mathrm{~m})$.

The maximum land-surface subsidence in the Port Acres area during 1959-77, as shown on Figure 4, is approximately 3 feet $(0.9 \mathrm{~m})$. The subsidence was determined by comparing 1959 and 1977 topographic maps of Jefferson County Drainage District No. 7 and by examining available releveling data. Measurements of the elevation of bench mark G1016 (Figure 4) show that during 1954-59, the bench mark subsided 0.07 foot $(0.021 \mathrm{~m})$ and that during $1959-73$, it subsided 2.89 feet $(0.88 \mathrm{~m})$. A comparison of the topographic maps indicated small but additional subsidence during 1973-77. Ground-water withdrawal in the Port Acres area was insufficient to cause land-surface subsidence of this magnitude.

The rapid increase in subsidence between 1959 and 1973 corresponds closely to the discovery and development of the Port Acres Gas Field in 1957. The producing zones of the field range in depth from 9,184 to 10,625 feet $(2,799$ to $3,238 \mathrm{~m})$. The compressibility of the sediments at these depths is unknown, but loading of the zone has been significant. Decreases in well-head pressures of as much as 5,100 pounds per square inch or $360 \mathrm{~kg} / \mathrm{cm}^{2}$ (Railroad Commission of Texas, unpublished records) have been measured. The most probable cause of land-surface subsidence in the Port Acres area is the withdrawal of oil, gas, and associated ground water.

Other areas of land-surface subsidence of more than 0.5 foot $(0.15 \mathrm{~m})$ occur in the eastern, central, and western parts of Orange County, in northern Jefferson County, and in two small areas in southeastern Jefferson County.

The subsidence in Orange County is related mainly to ground-water withdrawals. The subsidence in northern Jefferson County is in or near the City of Beaumont (Figure 2). The primary cause is not as apparent as it is in Orange County, but subsidence is probably caused by ground-water withdrawals. Although no well fields are directly associated with the area of subsidence in Beaumont, a well field is near the subsided area. Subsidence west of Beaumont is probably caused by the fluid withdrawals related to oil and gas production. There are no waterwell fields in the area to provide the necessary stress to the aquifer system to cause subsidence.

The area of subsidence in northwestern Jefferson County is probably caused by groundwater withdrawals. The two small areas in southeastern Jefferson County (Figure 2), where subsidence is greater than 0.5 foot $(0.15 \mathrm{~m})$, may be areas with local conditions of relatively large compressibility or undetected water-level declines. 


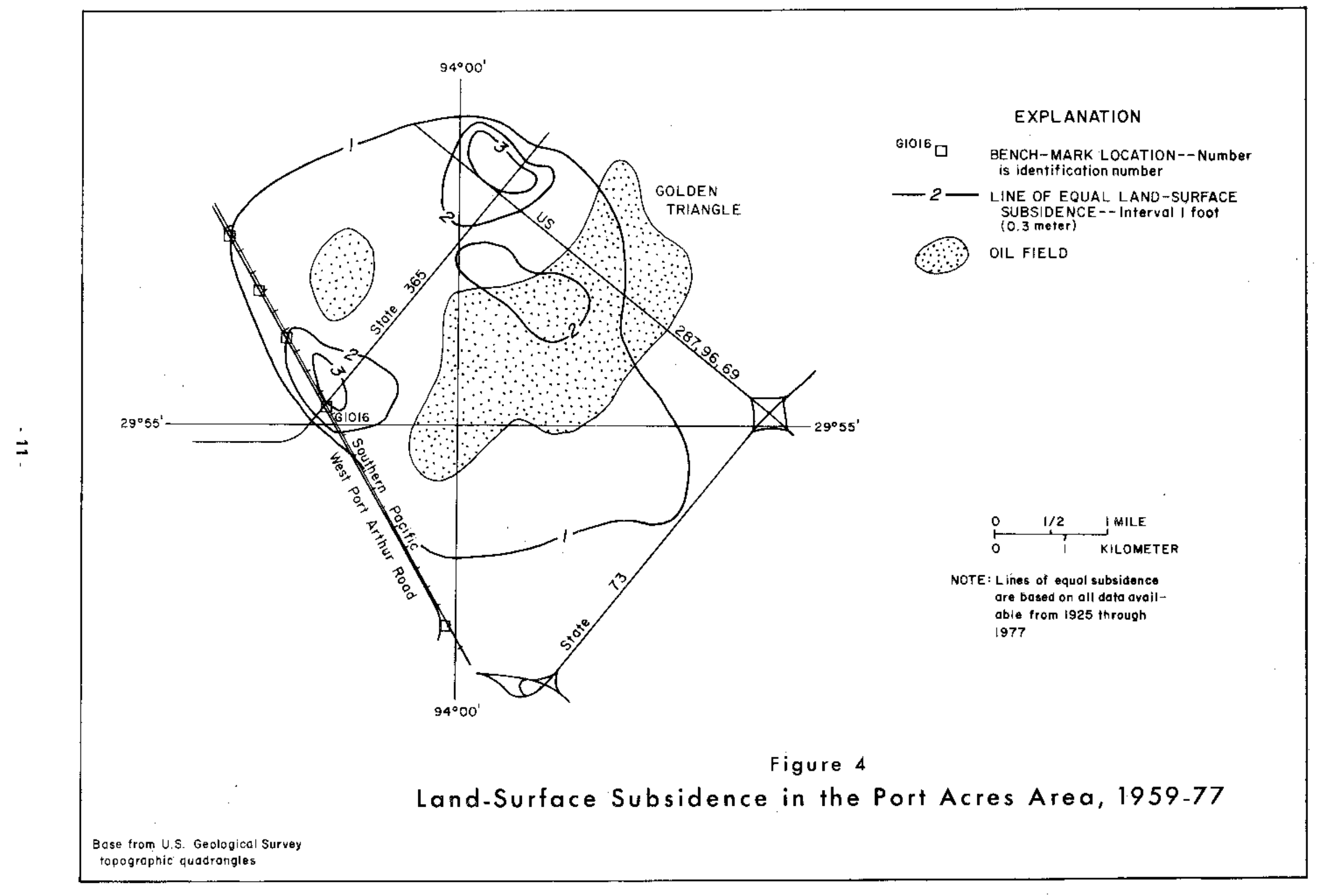




\section{Subregion 2}

Land-surface subsidence in the Houston-Galveston area of subregion 2 (Figure 5 ) has been well documented by Gabrysch and Bonnet (1975). Subsidence is generally greater than 0.5 foot $(0.15 \mathrm{~m})$, and the greatest measured amount, between 8.5 and 9.0 feet $(2.6$ and $2.7 \mathrm{~m})$, occurred in the Pasadena-Houston Ship Channel area.

The subsidence shown on Figure 5 was caused more by the withdrawal of ground water than by the withdrawal of oil, gas, and associated ground water. Local subsidence probably occurs in most of the oil and gas fields, but the control necessary to define the amount is not available.

Subsidence in the vicinity of Freeport in Brazoria County is caused by ground-water withdrawals from the shallow subsurface for municipal supply and industrial use. Subsidence in the vicinity of the Old Ocean Oil and Gas Field is probably the result of water-level declines rather than pressure declines due to oil and gas production.

Subsidence greater than 15 feet $(4.6 \mathrm{~m}$ ) was reported, but not measured (Wesseiman, 1971, p. 25), at the Moss Bluff Salt Dome on the Liberty-Chambers County line just east of the Trinity River (Figure 5). This subsidence was caused by sulfur production.

\section{Subregion 3}

Land-surface subsidence during $1918-73$ in subregion 3 (Figure 6) is generally less than 0.5 foot $(0.15 \mathrm{~m})$. An area of subsidence of at least 0.5 foot $(0.15 \mathrm{~m})$ extends into Matagorda and Victoria Counties from Jackson County, with the greatest amount of subsidence, more than 1.5 feet $(0.46 \mathrm{~m})$, in southeastern Jackson County and northwestern Matagorda County. The principal cause for the subsidence in subregion 3 is ground-water withdrawals.

Withdrawals of oil, gas, and associated ground water have probably caused the subsidence in the areas adjacent to the oil and gas fields. The subsidence at Bay City probably is the result of withdrawal of both fresh ground water and oil, gas, and associated ground water. The subsidence in eastern Matagorda County is probably caused by withdrawals of ground water for irrigation.

The large area of subsidence in the eastern one-half of Jackson County and the northwestern part of Matagorda County, most of which occurred between 1950 and 1973, is the result of declines in water levels resulting from an increase in ground-water withdrawa's for irrigation in the early 1950's (Loskot and others, 1982). The area of subsidence extending westward from Jackson County into Victoria County is also the result of an increase in ground-water withdrawals for irrigation.

Land-surface subsidence in southeastern Victoria County is probably related to oil and gas production. There are very few water wells and only a small amount of ground-water withdrawal in the subsided area. Water levels in observation wells within the subsided area declined more than 1 foot $(0.3 \mathrm{~m}$ ) from 1958 to 1973 (Texas Department of Water Resources, unpublished data); but these declines were not sufficient to cause the subsidence shown for the area. 


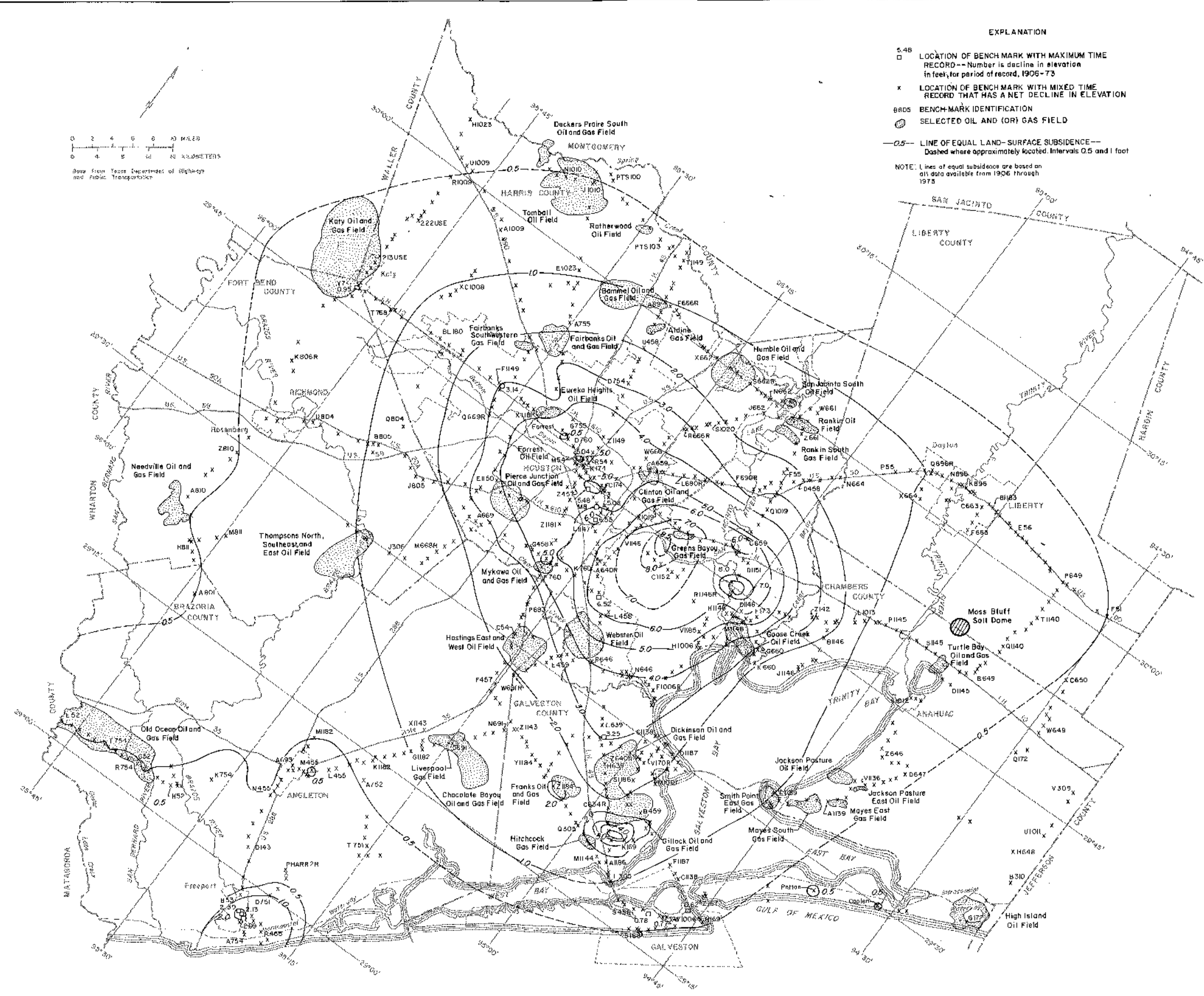

Figure 5

Land-Surface Subsidence in Subregion 2, 1906-73 


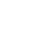




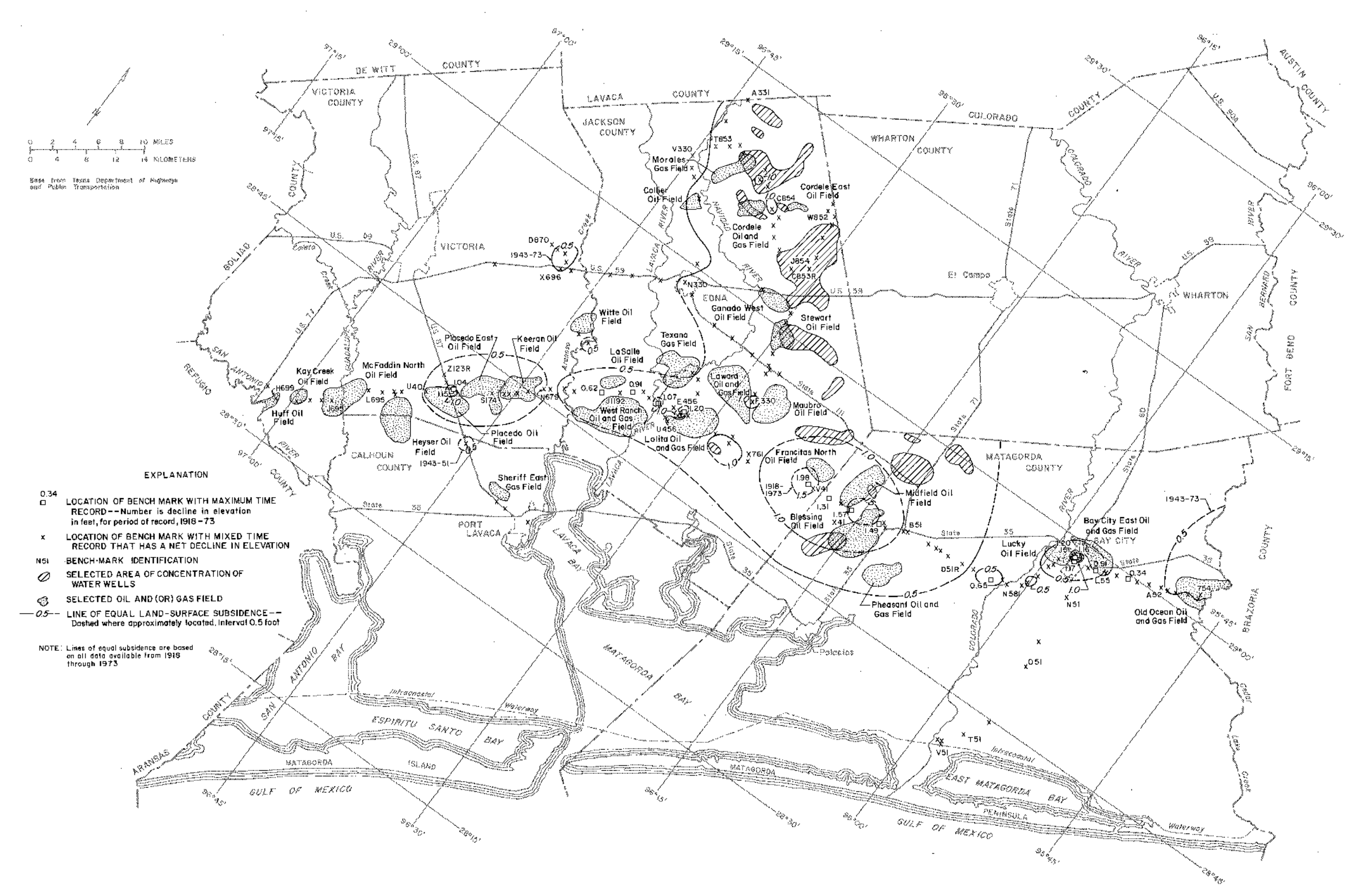

Figure 6

Land-Surface Subsidence in Subregion 3, 1918-73 



\section{Subregion 4}

;Land-surface subsidence in subregion 4 (Figure 7) is generally less than 0.5 foot $(0.15 \mathrm{~m})$. The maximum periods of record are 1918-51 in Refugio and San Patricio Counties and 1942-75 in Nueces County. The subsidence for these two periods is shown on Figure 7.

The two areas that have subsided more than 0.5 foot $(0.15 \mathrm{~m})$ are in the western part of Corpus Christi in Nueces County and in the southern part of Refugio in Refugio County. The maximum measured land-surface subsidence in Corpus Christi is 5.28 feet $(1.61 \mathrm{~m})$, which occurred between 1942 and 1975. There are no water wells in or near the subsided area in which the head decline has been large enough to cause subsidence. The outline of the subsidence bowl, which closely corresponds to the outline of the Saxet Oil and Gas Field; the comparative shallowness of the Saxet field $(4,060-8,100$ feet or $1,237-2,469 \mathrm{~m})$; and the lack of ground-water withdrawal indicates that the cause of the subsidence at Corpus Christi is the withdrawal of oil, gas, and associated ground water.

The maximum measured subsidence in Refugio is 0.74 foot $(0.23 \mathrm{~m})$, which occurred between 1918 and 1951. Approximately 90 percent of the subsidence occurred between 1918 and 1943.

It is not possible to determine the cause of subsidence from the data available. The few records of water levels that are available indicate that the deep welis, $800-900$ feet $(245-275 \mathrm{~m})$, were flowing wells. Mason (1963, p. 27) states that, "In most of the county, the water levels have declined in recent years due to increased pumping, and as a result, many wells have stopped flowing or their flows have decreased."

The water level in a deep well within the subsided area declined from 60 feet $(18 \mathrm{~m})$ above land-surface datum in 1937 to 19.7 feet $(6 \mathrm{~m})$ below land-surface datum in 1961 . This may have been enough reduction of head to cause the subsidence. The Refugio Old and Refugio New Oil and $G$ as Fields were discovered in 1920 and 1931, and the subsequent withdrawal of oil, gas, and associated ground water may have contributed to the subsidence.

\section{Subregion 5}

Maximum measured land-surface subsidence during 1917-51 in subregion 5 (Figure 8) was 0.42 foot $(0.13 \mathrm{~m})$.

In Brooks County, the early development of ground water was principally for public and domestic supply and livestock use (Myers and Dale, 1967). Irrigation increased rapidly in the early 1960 's.

In Kenedy County, ground-water development is mainly for domestic supply and livestock use in the central and western parts of the county (Baker and Dale, 1961). Most of the ground-water development in Hidalgo County for irrigation is in the southern and central parts of the county, while the development for domestic supply and livestock use is scattered throughout the county. 


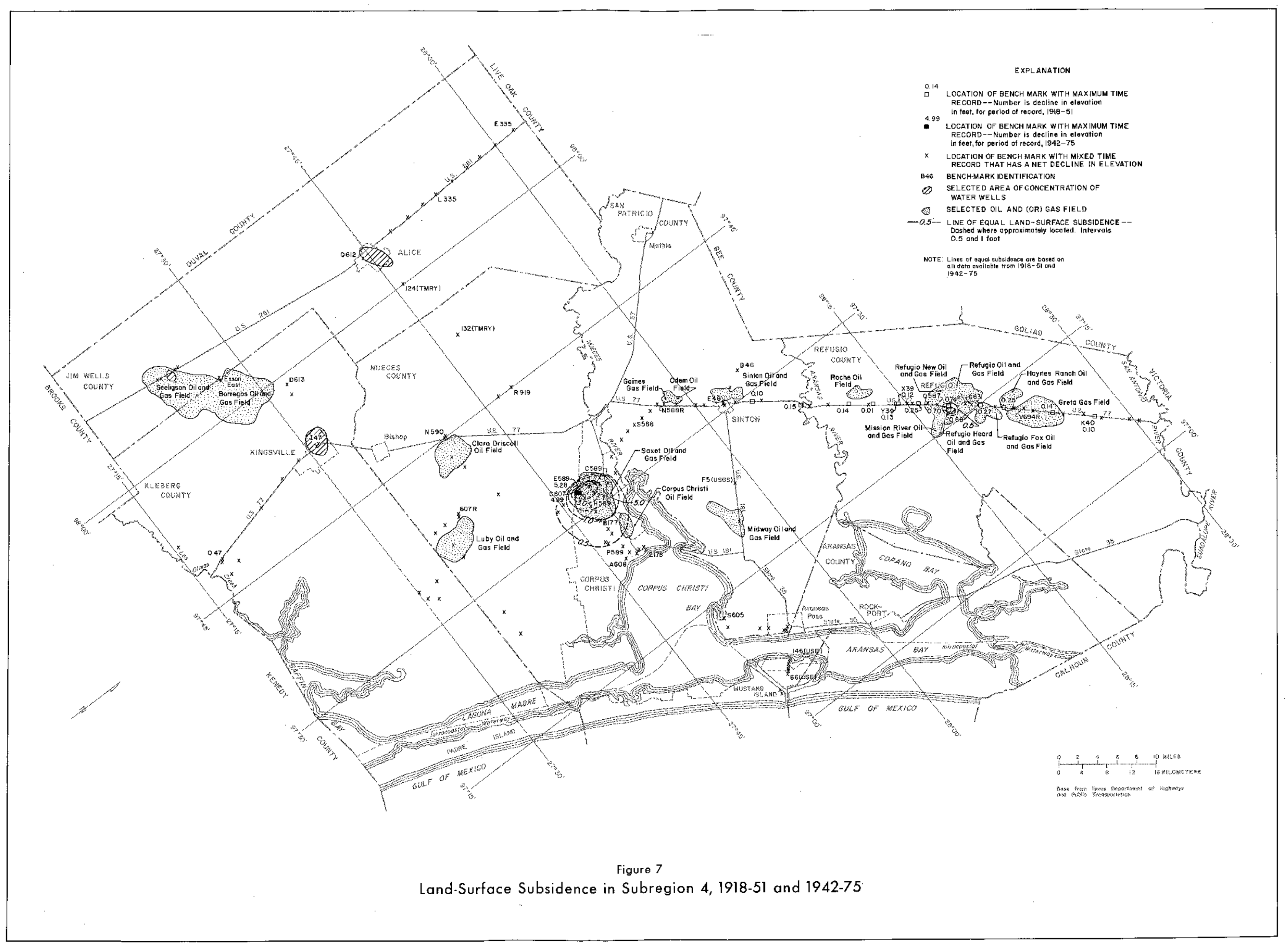



Almost all of the ground-water development in Cameron County is in the western one-half of the county. The majority of the development is for livestock use, domestic supply, and irrigation (Baker and Dale, 1961), but there is some industrial and public-supply development.

The decline in water levels in the subregion varies in amount, time, and extent. The greatest recorded declines are in Brooks County, where there has been at least 110 feet $(33.5 \mathrm{~m})$ of decline in the north-central and northeastern parts of the county from 1932-33 to 1964-65 (Myers and Dale, 1967). Water levels declined everywhere in Brooks County during that time except in the west-central part of the county.

Historical water-level records for Kenedy and Willacy Counties are not available, but it is known that in Kenedy County many of the wells that formerly flowed ceased to flow prior to 1968 (Shafer and Baker, 1973).

In Hidalgo County, water levels in the northern part of the county declined from 1947-48 to 1957-58. In the southern part of the county, the water levels rose from 1933 to 1945.

Water-level records from Cameron County are inadequate to determine water-level trends. However, the water levels probably followed the same trends as in Hidalgo County because ground-water development in both counties occurred about the same time and for the same purpose.

It is difficult to determine if subsidence has occurred in subregion 5 . As indicated, the decline in elevation at most of the bench marks is small, generally less than 0.1 foot $(0.03 \mathrm{~m})$. in fact, most of the bench-mark elevation differences in Cameron County are less than 0.5 foot $(0.015 \mathrm{~m})$. Many of these elevation differences are within the standard of accuracy mentioned earlier in this report. In southern Cameron County, bench mark U48, which had a 0.42-foot $(0.13-\mathrm{m})$ loss in elevation during 1917-51, is in an area where ground-water development did not occur until after 1949 .

If subsidence has occurred in the areas where repetitive levelings were made, the amounts are very small. In Brooks County, where water levels have declined, no subsidence has been detected because of the lack of repetitive leveling. 



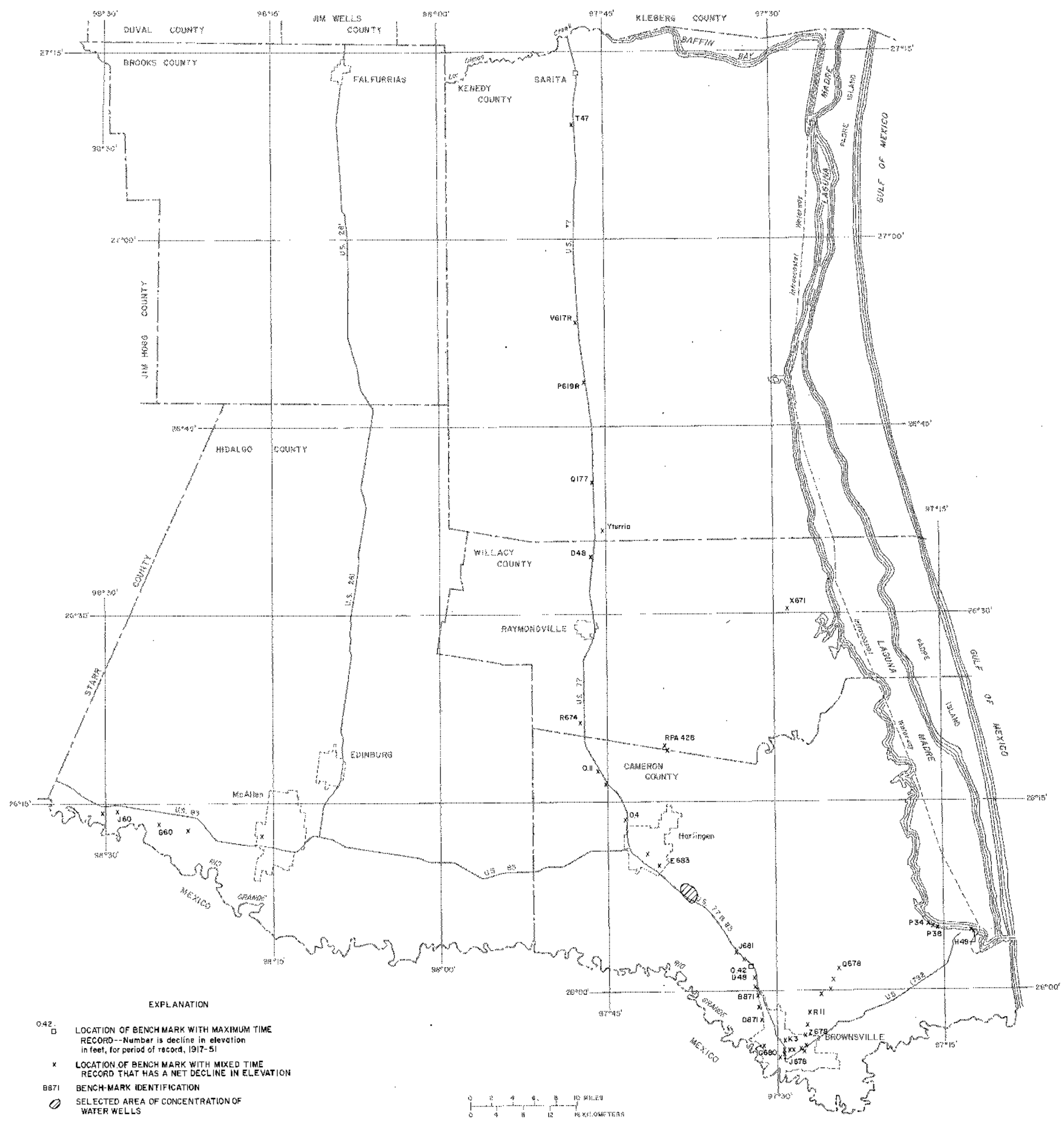

Figure 8

Land-Surface Subsidence in Subregion 5, 1917-51 

Anders, R. B., McAdoo, G. D., and Alexander, W. R., Jr., 1968, Ground-water resources of Liberty County, Texas: Texas Water Development Board Report 72, 154 p.

Baker, E. T., Jr., 1965, Ground-water resources of Jackson County, Texas:: Texas Water Development Board Report 1, $229 \mathrm{p}$.

1979, Stratigraphic and hydrogeologic framework of part of the coastal plain of Texas: Texas Department of Water Resources Report 236, 43 p.

Baker, E. T., Jr., and Follett, C. R., 1973, Effects of ground-water development on the proposed Palmetto Bend Dam and Reservoir: U.S. Geological Survey Water-Resources Investigations $73-18,70 \mathrm{p}$.

Baker, R. C., and Dale, O. C., 1961, Ground-water resources of the Lower Rio Grande Valley area, Texas: Texas Board of Water Engineers Bulletin 6014, vol. I, 88 p.; vol. II, 340 p.

Brown, L. F., Jr., Morton, R. A., McGowen, J. H., Kreitler, C. W., and Fisher, W. L., 1974, Natural hazards of the Texas Coastal Zone: University of Texas Bureau of Economic Geology, Special Atlas, $13 \mathbf{p}$.

Gabrysch, R. K., 1969, Land-surface subsidence in the Houston-Galveston region, Texas: Proceedings, International Symposium on Land Subsidence, Publication no. 88, AlHS, p. $43-54$.

Gabrysch, R. K., and Bonnet, C. W., 1975, Land-surface subsidence in the Houston-Galveston region, Texas: Texas Water Development Board Report 188, 19 p.

Hammond, W. W., 1969, Ground-water resources of Matagorda County, Texas: Texas Water Development Board Report 91, 163 p.

Loskot, C. L., Sandeen, W. M., and Follett, C. R., 1982, Ground-water resources of Colorado, Lavaca, and Wharton Counties, Texas: Texas Department of Water Resources Report 270 , $252 \mathrm{p}$.

Mason, C. C., 1963, Ground-water resources of Refugio County, Texas: Texas Water Commission Bulletin 6312, $122 \mathrm{p}$.

Muenster, R. A., and Michal, E. J., 1938, Records of wells, drillers' logs, water analyses, and maps showing locations of wells in Refugio County and part of Goliad County, Texas: Texas Board of Water Engineers duplicated report, $92 \mathrm{p}$.

Myers, B. N., and Dale, O. C., 1967, Ground-water resources of Brooks County, Texas: Texas Water Development Board Report 61, 95 p.

National Ocean Survey, 1974, Classification, standards of accuracy, and general specifications of geodetic control surveys: U.S. Department of Commerce, $12 \mathrm{p}$. 
Poland, J. F., and Davis, G. H., 1969, Land subsidence due to withdrawal of fluids in Varnes, D. J., and Kiersch, George, eds., Reviews in Engineering Geology: Boulder, Colorado, Geologic Society of America, vol. 2, p. 187-269.

Sandeen, W. M., and Wesselman, J. B., 1973, Ground-water resources of Brazoria County, Texas: Texas Water Development Board Report 163, $197 \mathrm{p}$.

Shafer, G. H., and Baker, E. T., Jr., 1973, Ground-water resources of Kleberg, Kenedy, and southern Jim Wells Counties, Texas: Texas Water Development Board Report 173, $169 \mathrm{p}$.

Turcan, A. N., Jr., Wesselman, J. B., and Kilburn, Chabot, 1966, Interstate correlation of aquifers, southwestern Louisiana and southeastern Texas: U.S. Geological Survey Professional Paper 550-D, p. D231-236.

Wesselman, J. B., 1965, Geology and ground-water resources of Orange County, Texas: Texas Water Commission Bulletin 6516, $112 \mathrm{p}$.

1967, Ground-water resources of Jasper and Newton Counties, Texas: Texas Water Development Board Report 59, $173 \mathrm{p}$.

1971, Ground-water resources of Chambers and Jefferson Counties, Texas, with a section on Quaternary Geology by Saul Aronow: Texas Water Development Board Report 133. $183 \mathrm{p}$.

1972, Ground-water resources of Fort Bend County, Texas: Texas Water Development Board Report 155, $176 \mathrm{p}$.

Winslow, A. G., and Doyel, W. W., 1954, Land-surface subsidence and its relation to the withdrawal of ground water in the Houston-Galveston region, Texas: Economic Geology, vol. 49 , no. 4 , p. 413-422.

Winslow, A. G., and Wood, L. A., 1959, Relation of land subsidence to ground-water withdrawals in the upper Gulf Coast Region, Texas: Mining Engineering, vol. 11, no. 10, p. 10301034. 
. 

, 

